\title{
PENERAPAN SYIRKAH MELALUI AKAD MUSYARAKAH BASMALAH SIDOGIRI PASURUAN 1
}

\author{
Amirul Taufiqulhakim \\ Departemen Ekonomi Syariah - Fakultas Ekonomi dan Bisnis - Universitas Airlangga \\ Email: amirultaufiqulhakim@yahoo.co.id \\ Achsania Hendratmi \\ Departemen Ekonomi Syariah - Fakultas Ekonomi dan Bisnis - Universitas Airlangga \\ Email: achsania.hendratmi@feb.unair.ac.id
}

\begin{abstract}
:
The purpose of this study was to find out the process of applying the Musyarakah contract carried out by Basmalah Sidogiri in Pasuruan with its partners in opening new branches and investing as new members. This study uses qualitative methods using explanative case study methods. Primary data collection is conducted by interviews and direct observation to informants, they are Head of Marketing Division, Head of Finance Division, Basmalah Partners in Surabaya, and Investors. Secondary data collections are from journals, books, BPS, Web of Basmalah, and other literature.
\end{abstract}

\section{Keywords: Musyarakah Contract, Basmalah, Sidogiri}

\section{PENDAHULUAN}

Perkembangan ekonomi berbasis syariah sudah dikenal luas oleh masyarakat Indonesia. Masyarakat umum di Indonesia cenderung mengenal murabahah dalam transaksi pembiayaan syariah. Menurut Karim (2007) menyatakan bahwa masyarakat umum di Indonesia cenderung mengenal metode proporsional dalam transaksi pembiayaan syariah. Sistem ekonomi syariah pada dasarnya juga memberikan pembiayaan syariah bagi para pedagang. Pembiayaan syariah memiliki beberapa macam jenis meliputi: Murabahah, Musyarakah, Mudharabah, syirkah,ijarah, Wakalah, Kafalah, Hawalah, dan Qardh(Adnan dan Furywardhana dalam Falikhatun, 2017: 63)

Salah satu sistem syariah yang sering diterapkan dalam perdagangan yaitu mengharuskan adanya akad atau perjanjian antara pengelola dengan pedagang yang diatur menggunakan sistem musyarakah. Al-Zuhaili mendefinisikan syirkah sebagai bentuk kerjasama antara dua orang atau lebih yang terikat dalam suatu usaha perjanjian guna melakukan usaha secara bersamasama serta memperoleh keuntungan dan kerugian yang ditentukan sesuai dengan perjanjian (Ghadas \& Ali, 201 1: 307). Prinsip bagi hasil dalam musyârakah ini berbeda dengan prinsip bunga tetap. Bank akan menagih penerima pembiayaan (nasabah) satu jumlah bunga tetap berapa pun keuntungan yang dihasilkan nasabah, bahkan sekalipun merugi dan terjadi krisis ekonomi. Dalam Al-Qur'an dijelaskan pada surat shad ayat 24 sebagai berikut:

\footnotetext{
${ }^{1}$ Jurnal ini merupakan bagian dari skripsi yang ditulis oleh Amirul Taufiqulhakim, NIM: 041311433050, yang diuji pada 22 Juli 2019.
} 


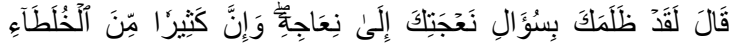

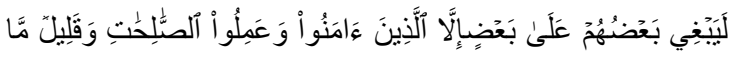

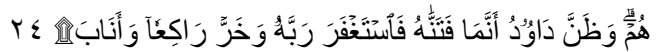
Artinya: Daud berkata: "sesungguhnya dia telah berbuat zalim kepadamu dengan meminta kambingmu itu untuk ditambahkan kepada kambingnya. Dan sesungguhnya kebanyakan dari orang-orang yang berserikat itu sebahagian mereka berbuat zalim kepada sebahagian yang lain, kecuali orang-orang yang beriman dan mengerjakan amal yang saleh dan amat sedikitlah mereka ini". (Departemen agama Rl, 2006)

Salah satu bisnis yang menerapkan sistem kerjasama berbasis syariah dan dilakukan oleh kelompok atau organisasi dapat ditemui pada Lembaga Keungangan Non Bank (LKNB), yaitu koperasi pondok pesantren (kopontren).Koperasi pondok pesantren adalah koperasi yang didirikan oleh pondok pesantren dan berjalan berdasarkan prinsip syariah Islam.

Menurut dinas UMKM Provinsi Jawa Timur (2018), Kementrian Koperasi dan UMKM menilai potensi pondok pesantren (ponpes) cukup strategis sebagai pusat pemberdayaan ekonomi umat, karena jumlahnya cukup besar. Berdasarkan data dari Kementrian Agama jumlah ponpes saat ini mencapai 27.290 unit dengan tenaga pendidik 160.793 orang dan santri 3.876.696 orang.Salah satu daerah di Indonesia dengan jumlah koperasi yang cukup banyak adalah di Pulau Jawa. Menurut data Badan Pusat Statisik (BPS)
Indonesia tahun 2013 hingga 2016 jumlah koperasi di pulau Jawa adalah yang paling banyak dibandingkan dengan pulau-pulau lain di Indonesia. Adapun data koperasi berdasarkan provinsi di pulau Jawa adalah sebagai berikut table 1:

Tabel 1.

Data Jumlah Koperasi

\begin{tabular}{|c|c|c|c|c|}
\hline Tahun & \multirow[t]{2}{*}{2013} & \multirow[t]{2}{*}{2014} & \multirow[t]{2}{*}{2015} & \multirow[t]{2}{*}{2016} \\
\hline Provinsi & & & & \\
\hline Jawa Barat & 15.13 & 15.633 & 16.855 & 16.289 \\
\hline $\begin{array}{l}\text { Jawa } \\
\text { Tengah }\end{array}$ & 21.832 & 22.563 & 23.059 & 21.434 \\
\hline Jawa Timur & 25.552 & 27.14 & 27.472 & 26.519 \\
\hline $\begin{array}{c}\text { DI } \\
\text { Yogyakarta }\end{array}$ & 2.172 & 2.269 & 2.369 & 1.745 \\
\hline DKI Jakarta & 5.579 & 5.645 & 6.016 & 5.063 \\
\hline
\end{tabular}

Sumber: Badan Pusat Statistik, 2014(data diolah)

Berdasarkan pada tabel 1 tersebut Jawa Timur merupakan provinsi dengan jumlah koperasi aktif yang paling banyak yaitu 26.519 unit pada tahun 2014 dan Jawa Timur berada pada posisi pertama dengan 26.519 unit, termasuk di dalamnya adalah koperasi pondok pesantren yang menerapkan prinsip syariah. Tabel 1 juga menunjukkan bahwa Jawa Timur merupakan salah satu provinsi potensial dalam penerapan koperasi baik yang berbasis konvensional maupun syariah di Indonesia.

Salah satu koperasi dengan sistem syariah Islam dan berbasis Pondok Pesantren adalah Kopontren Sidogiri di Pasurvan Jawa Timur yang masih berada 
Taufiqulhakim, et al/Jurnal Ekonomi Syariah Teori dan Terapan Vol. 6 No. 10 Oktober 2019: 2143-2157; PENERAPAN SYIRKAH MELALUI AKAD MUSYARAKAH BASMALAH SIDOGIRI PASURUAN

di bawah naungan Pondok Pesantren Sidogiri. Banyaknya penduduk muslim Indonesia terutama Jawa Timur menjadikan bisnis Koperasi Pondok Pesantren Sidogiri tergolong menjanjikan. Koperasi Pondok Pesantren Sidogiri merupakan koperasi syariah yang lahir sebagai wadah bagi para santri serta masyarakat sekitar yang ada di pondok pesantren sidogiri agar dapat mengembangkan jiwa berwirausaha dalam dirinya.

Koperasi Pondok Pesantren Sidogiri ini didirikan oleh KA.Sa'doellah Nawawie (Penanggung Jawa dan Ketua Pengurus Ponpes Sidogiri) pada tahun 1961 yang merintis berdirinya koperasi sebagai wadah untuk belajar kemandirian, wirausaha (entrepreneurship) dan pengadian bagi para santri.Kegiatan usaha pertamanya adalah membuka kedai dan warung kelontong di lingkungan pesantren yang menyediakan kebutuhan sehari-hari bagi para santri. Meski berdiri sejak 1961, namun Koperasi Pondok Pesantren Sidogiri resmi berbadan hukum mulai 15 Juli 1997. Sejak saat itulah kopontren Sidogiri terus berkembang pesat hingga pada tahun 2013 Koperasi Pondok Pesantren Sidogiri melakukan perubahan nama brand menjadi 'BASMALAH' atau saat ini lebih banya dikenal sebagai Toko Basmalah di Sidogiri, Kraton, Pasuruan, Jawa Timur.

Seiring dengan berjalannya waktu pengasuh Pondok Pesantren (ponpes) Sidogiri Kyai Kholil, membentuk struktur kepengurusan yang maksudnya adalah memberikan kepercayaan penuh kepada pengurus yang berkompeten untuk menjalankan bisnis koperasi di lingkungan pondok pesantren. Toko Basmalah yang bergerak di sektor rill yang tersebar di Jawa Timur dan Kalimantan sebanyak 150 unit.Basmalah adalah konsep dari Barakah, Syariah dan Maslahah. Berbeda dengan retail modern yang bersiat kapitalis, karena hadirnya toko Basmalah dengan visi menggandeng dan menggendong toko-toko kecil dan Usaha Kecil dan Menengah (UKM) masyarakat sekitar sehingga mampu meningkatkan perekonomian dan kesejahteraan mitra Kopontren. Pesatnya perkembangan Kopontren sidogiri dapat dilihat dari banyaknya jumlah anggota Kopontren yang terus meningkat setiap tahunnya, data tersebut dapat dilihat pada tabel 2 sebagai berikut:

Tabel 2.

\section{Keanggotaan Kopontren Sidogiri Tahun} 2011-2013

\begin{tabular}{|c|c|}
\hline Tahun & Jumlah anggota \\
\hline 2010 & 471 \\
\hline 2011 & 947 \\
\hline 2012 & 1091 \\
\hline 2013 & 1426 \\
\hline
\end{tabular}

Sumber: Syaiful, 2014

Tabel di atas menunjukkan bahwa anggota Kopontren Sidogiri memiliki anggota yang meningkat dalam kurun waktu tahun secara cepat. Pada 2010 hingga 2011 hanya terdapat 471 anggota. Pada tahun 2011 hingga 2012 
Taufiqulhakim, et al/Jurnal Ekonomi Syariah Teori dan Terapan Vol. 6 No. 10 Oktober 2019: 2143-2157; PENERAPAN SYIRKAH MELALUI AKAD MUSYARAKAH BASMALAH SIDOGIRI PASURUAN

terjadi kenaikan jumlah anggota sebanyak 144 anggota, sedangkan pada tahun 2012 hingga 201 terjadi kenaikan jumlah anggota sebanyak 345 anggota. Terdapat 3 kategori keanggotaan dalam Kopontren Sidogiri yaitu, anggota khusus yaitu pondok pesantren sidogiri yang diwakili oleh Ketua Umum pondok pesantren Sidogiri, anggota biasa dan anggota luar biasa. Bertambahnya jumlah anggota Kopontren juga menambah jumlah modal yang dihimpun dari masyrakat, hal tersebut dapat dilihat berdasarkan data pada tabel 3 sebagai berikut:

Tabel 3.

Modal Kopontren Sidogiri Tahun 2009-2013

\begin{tabular}{|c|c|}
\hline Tahun & Jumlah modal \\
\hline 2009 & $3,962,813,073$ \\
\hline 2010 & $5,140,819,819$ \\
\hline 2011 & $10,750,364,826$ \\
\hline 2012 & $14,573,450,187$ \\
\hline 2013 & $23,008,891,106$ \\
\hline
\end{tabular}

Sumber: Syaiful, 2014

Berdasarkan tabel 3 di atas dapat diketahui bahwa kenaikan jumlah modal yang dihimpun oleh Kopontren Sidogiri setiap tahunnya juga mengalami peningkatan.Pada tahun 2009 mencapai 3 milyar dan mengalami kenaikan signifikan mencapai angka 23 milyar pada tahun 2013. Angka tersebut menunjukkan adanya peningkatan yang sangat signifikan, sehingga dapat disimpulkan bahwa kenaikan jumlah anggota juga akan meningkatkan jumlah modal yang dihimpun dari masyarakat
Banyaknya jumlah anggota Basmalah membuat proses pengembangan toko cabang baru berjalan cepat, karena konsep yang diterapakan oleh toko Basmalah dalam membuka cabang baru adalah dengan menghimpun dana dari anggota dan juga investor. Secara singkat konsep yang diterapkan oleh toko Basmalah dapat disebut sebagai konsep bisnis berjamaah dimana Basmalah mengajak dan memanfaatkan semua orang sebagai mitra usaha yang bertujuan agar mereka dapat bersaing dengan industri besar yang lebih condong bersifat kapitalis.

Adapun akad yang digunakan dalam syirkah atau kerjasama Kopontren adalah dengan menerapkan kerjasama menggunakan akad mudharabah, musyarakah, ijarah, dan nadzah lajaj.Pengggunaan akad-akad ini memiliki tujuan masing-masing demi tercapainya kesejahteraan antara toko Basmalah dengan mitra toko Basmalah menjunjung tinggi dengan nilai-nilai bisinis berbasis Islam.Syirkah atau kerjasama yang dilakukan pihak toko Basmalah dengan mitranya dalam mengembangkan bisnis melalui pembukaan cabang baru lebih condong menggunakan akad musyarakah.

Akad musyarakah sendiri telah diterapkan oleh toko Basmalah dengan mitranya sejak tahun 2004.Terdapat beberapa keunggulan yang dimiliki dalam akad musyarakah diantaranya kemudahan dalam berinvestasi, tidak 
Taufiqulhakim, et al/Jurnal Ekonomi Syariah Teori dan Terapan Vol. 6 No. 10 Oktober 2019: 2143-2157; PENERAPAN SYIRKAH MELALUI AKAD MUSYARAKAH BASMALAH SIDOGIRI PASURUAN

terikat pada jangka waktu tertentu, dan adanya ketentuan bagi hasil yang menjanjikan. Berdasarkan fakta-fakta yang telah disebutkan diatas, peneliti tertarik meneliti lebih jauh mengenai cara toko Basmalah memberikan treatment dalampenerapan syirkah atau kerjasama dengan anggotanya serta investornya melalui penerapan akad musyarakah sehingga dapat menyejarterakan dirinya sendiri di masa depan.

Berdasarkan latar belakang yang telah diuraikan maka rumusan masalah dalam penelitian ini antara lain:Bagaimana penerapan syirkahmelalui akad musyarakah Basmalah Sidogiri Pasurvan?

\section{LANDASAN TEORI}

\section{Koperasi}

Secara etimologi koperasi berasal dari bahasa Inggris, yaitu cooperation (co: bersama dan operation: kerja) yang artinya bekerja sama. Sedangkan secara terminologi, koperasi adalah suatu perkumpulan atau organisasi yang beranggotakan badan hukum atau orang-orang yang bekerja sama dengan penuh kesadaran untuk meningkatkan kesejahteraan anggota atas dasar sukarela seara kekeluargaan. Menurut Undang-Undang No. 12 tahun 1967 tentang pokok-pokok perkoperasian, koperasi Indonesia adalah organisasi ekonomi rakyat berwatak sosial, beranggotakan orang-orang atau badan hukum koperasi yang merupakan tata susunan ekonomi sebagai usaha bersama berdasar atas asas kekeluargaan.

\section{Koperasi Syariah}

Lembaga Kevangan Syariah (LKS) terdiri dari dua kelompok lembaga, yakni lembaga keuangan berbentuk bank dan lembaga keuangan berbentuk bukan bank.Lembaga keuangan yang berbentuk bank mencakup Bank Umum Syariah (BUS) dan Bank Pembiayaan Rakyat Syariah (BPRS). Sedangkan lembaga keuangan yang bukan berbentuk bank adalah Unit Usaha Syariah (UUS) dan bait al Maal al Tamwil (BMT).

Berdasarkan Keputusan Menteri Negara Koperasi dan Usaha Kecil dan Menengah Republik Indonesia Nomer 91/Kep/KUKM/IX/ 2004 tentang petunjuk Pelaksanaan Kegiatan Usaha Koperasi jasa Keuangan Syariah memberikan pengertian bahwa koperasi simpan pinjam syariah atau koperasi jasa kevangan syariah adalah koperasi yang kegiatan usahanya bergerak di bidang pembiayaan, investasi, simpanan sesuai pola bagi hasil (syariah). Dengan demikian semua BMT yang ada di Indonesia dapat digolongkan dalam KJKS, mempunyai payung hukum dan legal kegiatan operasionalnya asal saja memenuhi ketentuan perundangundangan yang berlaku.

\section{Muamalah}

Muamalah adalah hubungan antara manusia dalam usaha mendapatkan alat-alat kebutuhan jasmaniah dengan cara sebaik-baiknya 
sesuai dengan ajaran-ajaran dan tuntunan agama (Nasrun Haroen, 2007:3). Agama Islam memberikan norma dan etika yang bersifat wajar dalam usaha mencari kekayaan untuk memberi kesempatan pada perkembangan hidup manusia dibidang muamalah dikemudian hari. Islam juga memberikan tuntutan supaya perkembangan itu jangan sampai menimbulkan kesempitan-kesempitan salah satu pihak dan kebebasan yang tidak semestinya kepada pihak lain.

\section{Syirkah}

Secara bahasa syirkah berarti kemitraan. Kemitraan merupakan salah satu strategi bisnis yang dilakukan oleh dua pihak atau lebih dalam jangka waktu tertentu untuk meraih keuntungan bersama dengan prinsip saling membutuhkan dan saling membesarkan (Retnaningsih, 2017: 2). Kemitraan sangat ditentukan oleh adanya kepatuhan diantara yang bermitra dalam menjalankan etika bisnis. Dalam konteks ini pelaku-pelaku yang terlibat langsung dalam kemitraan harus memiliki dasardasar etika bisnis yang dipahami bersama dan dianut bersama sebagai titik tolak dalam menjalankan kemitraan (Ghadas \& Ali, 2011 : 307). Penerapan pola kemitraan bertujuan untuk mengatasi masalah keterbatasan modal dan teknologi, peningkatan mutu produk, harga jual yang tidak memadai, biaya produksi yang relatif tinggi, dan masalah pemasaran.

\section{Musyarakah}

Secara bahasa, syirkah adalah bercampurnya antara harta yang satu dengan harta yang lainnya sehingga keduanya tidak bisa dibedakan lagi. Sedangkan menurut syara"musyarakah adalah suatu akad antara dua pihak atau lebih yang sepakat untuk melakukan kerja dengan tujuan memperoleh keuntungan.(Wahbah Zuhaili,Fiqih Islam 5.2011:441) Jadi, dari pengertian di atas bisa disimpulkan bahwa musyarakah merupakan akad kerja sama antara dua pihak atau lebih, masingmasing pihak memberikan kontribusi dana untuk membiayai suatu usaha tertentu baik usaha yang sudah berdiri ataupun baru, dimana keuntungan dan kerugian dibagi bersama sesuai dengan kesepakatan.

\section{METODE PENELITIAN}

Penelitian ini menggunakan metode kualitatif karena mengipretasikan, menyoroti, dan menjelaskan suatu fenomena unik.Penelitian yang dipilih penulis adalah penelitian kualitatif dengan metode penelitian studi kasus.

Alasan digunakanya studi kasus dalam penelitian ini adalah :pertama, studi kasus meminimalisir terjadinya manipulasi hasil penelitian karena peneliti hanya memiliki sedikit peluang untuk mengontrol peristiwa yang akan terjadi. Kedua, studi kasus merupakan strategi yang sesuai dengan pertanyaan dalam penelitian yani bagaimana. Ketiga, fokus penelitian terletak pada fenomena kontemporer (masa kini) dalam kehidupan 
Taufiqulhakim, et al/Jurnal Ekonomi Syariah Teori dan Terapan Vol. 6 No. 10 Oktober 2019: 2143-2157; PENERAPAN SYIRKAH MELALUI AKAD MUSYARAKAH BASMALAH SIDOGIRI PASURUAN

nyata. Sehingga dapat ditarik kesimpulan bahwa studi kasus merupakan suatu metode kajian empiris untuk menyelidiki fenomena yang terjadi di kehidupan nyata bilamana batas-batas fenomena kehidupan nyata dengan konteks tidak jelas dengan menggunakan berbagai sumber data.

\section{Jenis dan Sumber Data}

Sumber data yang digunakan dalam penelitian ini adalah data primer dan data sekunder. Data primer merupakan data yang diperoleh secara langsung dari pihak pertama. Data primer dalam penelitian ini bersumber hasil wawancara yang dilakukan dengan empat informan. Dimana dua informan dari pihak manajemen dan dua informan lainnya dari pihak mitra. Dalam hal ini peneliti bertujuan untuk mengetahui seberapa jauh penerapan syirkah melalui akad musyarakah Basmalah Sidogiri Pasuruan. Adapun rincian informan yang digunakan dalam penelitian ini adalah:Informan pertama adalah bapak Syaiful sebagai Kepala Divisi Marketing.Informan kedua adalah bapak Nijar sebagai Kepala Divisi Keuangan. Informan ketiga adalah bapak Munadji sebagai pengusaha penjual madu mitra Basmalah yang menanam modal. Informan keempat adalah bapak Andre sebagai pemilik toko Basmalah cabang Surabaya.

Pemilihan narasumber dalam penelitian ini dengan menggunakan teknik purposive sampling, yaitu penentuan narasumber yang didasarkan pada pertimbangan.

\section{Prosedur Pengumpulan Data}

Yin (2009:103) menjelaskan bahwa ada enam sumber bukti yang dijadikan fokus bagi pengumpulan data studi kasus, yaitu dokumentasi, rekaman arsip, wawancara, observasi langsung, observasi partisipasi, dan perangkatperangkat fisik. Adapun sumber yang dilakukan di penelitian ini, secara spesifik ialah :

a. Dokumentasi atau Pengumpulan Catatan

Dokumen merupakan salah satu data penting dalam mendukung atau melengkapi bukti dari sumber lain

b. Wawancara

Yin (2009:111) menyatakan bahwa studi kasus umumnya berkaitan dengan urusan manusia, maka harus diintrepretasikan melalui penglihatan pihak yang diwawancarai dan para responden yang memiliki informasi dapat menginformasikan hal penting dan baik ke dalam situasi yang berkaitan

c. Observasi atau Pengamatan

Proses observasi dilakukan untuk mendukung pengumpulan data dari tahap wawancara. Dalam penelitian ini, akan dilakukan melalui teknik observasi partisipatif

\section{Teknik Validasi}

Data yang diperoleh dari wawancara, observasi, dan 
dokumentasi akan di uji validitasnya dengan cara triangulasi .Dalam penelitian ini ada metode triangulasi untuk menguji validitas, yaitu dengan:

Triangulasi sumber data. Berguna untuk menguji kredibiitas data yang diperoleh pada saat observasi di lapangan dengan cara melakukan pengecekan sumber data kepada beberapa sumber. Pengecekan ditujukan kepada, yaitu Ketua Pengurus Koperasi Pondok Pesantren Sidogiri, Mitra Toko Basmalah, pelaku usaha di sekitar kawasan Sidogiri Pasuruan

\section{Teknik Analisis}

Analisis data dalam penelitian kualitatif dilakukan sejak sebelum memasuki lapangan, selama di lapangan dan setelah selesai di lapangan. Namun analisis data lebih difokuskan selama proses di lapangan bersamaan dengan pengumpulan data (Sugiyono, 2013).

1. Analisis Sebelum di Lapangan

Analisis dilakukan terhadap data hasil studi pendahuluan, atau data sekunder yang akan digunakan untuk menentukan fokus penelitian.

2. Analisis Selama di Lapangan model Miles dan Huberman

Miles dan Huberman, sebagaimana dikutip Sugiyono (2012), mengemukakan bahwa aktivitas dalam analisis data kualitatif dilakukan secara interaktif dan berlangsung secara terus menerus sampai tuntas. Analisis data tersebut dilakukan dengan cara reduksi data, penyajian data, verifikasi, dan penarikan kesimpulan.

a. Reduksi Data

Miles dan Huberman dalam Sugiyono (2012) menjelaskan bahwa reduksi data adalah proses pemilihan, pemusatan perhatian pada penyederhanaan, pengabstrakan, dan tranformasi data kasar yang muncul dari catatan yang tertulis di lapangan. Mereduksi data berarti meringkas data, memilih hal pokok, dan memfokuskan data dengan mencari tema sesuai yang dibutuhkan dalam penelitian.Tujuan dalam penelitian kualitatif adalah menemukan sebuah temuan.

b. Penyajian Data

Miles dan Huberman dalam Sugiyono (2012) menjelaskan bahwa penyajian data adalah sekumpulan informasi yang telah tersusun dan memberikan kemungkinan untuk dilakukannya penarikan kesimpulan dan pengambilan tindakan berikutnya.Penyajian data dapat disajikan dalam bentuk teks naratif, bagan dan tabel yang diperoleh dari wawancara dan observasi lapangan.

c. Verifikasi dan Penarikan Kesimpulan 
Kesimpulan dalam penelitian kualitatif bisa jadi menjawab rumusan dan fokus penelitian yang telah ditentukan di awal, namun mungkin juga tidak.Kesimpulan dalam penelitian kualitatif yang diharapkan adalah merupakan temuan baru yang belum pernah ada.

d. Analisis Data Selama di Lapangan Mode Spradley

Dalam penelitian ini dilakukan teknik analisis yaitu, Analisis Domain, analisis ini berupaya untuk memperoleh gambaran yang umum dan menyeluruh dari obyek/penelitian atau situasi sosial, dalam melakukan analisis ini akan ditemukan domain dan kategori. Domain yang akan di pilih adalah syariah, mitra pedagang, system syirkah, musyarakah, serta hal-hal yang akan ditemukan di lapangan yang berkaitan dengan sistem akad Syirkah pada Toko Basmalah sidogiri Pasuruan.

\section{PEMBAHASAN}

\section{Penerapan Akad Musyarakah dalam Pembukaan Cabang Baru}

Toko Basmalah telah memiliki banyak cabang yang tersebar di seluruh Indonesia, salah satu faktor pesatnya pertumbuhan cabang toko Basmalah adalah dibukanya peluang menjadi investor Basmalah.Terdapat 2 pintu yang dibuka oleh pihak Basmalah dalam pembukaan cabang baru, yang pertama adalah melalui pintu tahunan bagi para investor yang dibuka antara bulan Januari-Februari per tahunnya atau dapat juga disebut sebagai investor umum.Selanjutnya, adalah melalui ekspansi langsung yang dilakukan oleh pengurus toko Basmalah ketika membutuhkan modal untuk membuka cabang baru.

Banyaknya pilihan akad yang diberikan kepada investor merupakan salah satu usaha dari pihak Kopontren untuk kemudahan dalam berinvestasi dengan tetap menerapkan aktivitas bisnis berbasis syariah dan berdasar kepada kitab Allah SWT. Adapun beberapa akad yang digunakan oleh toko Basmalah dalam pembukaan cabang baru adalah mudharabah, musyarakah, ijaraha dan nadzar lajaj,namun, akad musyarakah merupakan akad yang paling banyak digunakan oleh pihak Basmalah dalam pembukaan cabang baru. Penerapan akad-akad dalam pambukaan cabang baru toko Basmalah ini mulai diterapkan sejak tahun 2006.Porsi dari akad-akad lain dalam pembukaan cabang baru tidaklah banyak, seperti halnya akad mudharabah yang hanya memiliki persentase sebanyak 10\% dalam pembukaan cabang baru.Akad musyarakah juga lebih dominan digunakan karena dalam musyarakah diterapkan prinsip bisnis secara bersama-sama, dimana ketika sebuah 
bisnis dijalankan bersama-sama juga akan membawa nilai keberkahan di mata Allah SWT

Adapun secara singkat proses pembukaan cabang baru dilakukan dengan cara mengajukan proposal kerjasama dengan pihak Basmalah atau menghubungi bapak Saiful selaku Kadiv. marketing, untuk kemudian berdiskusi ingin melakukan syikah dengan menggunakan akad yang mana. Banyaknya alumni Pondok pesantren (Ponpes) Sidogiri juga mempengaruhi minat masyarakat dalam berinvestasi karena kekuatan dari alumni Ponpes Sidogiri sendiri telah mendapat kepercayaan dari masyarakat luas. Selanjutnya, setelah pengajuan modal dengan akad tertentu telah disetujui pihak Basmalah pusat akan melakukan survei lahan, apabila lahan yang dibutuhkan sesuai dengan kriteria yang ditentukan maka akan dilakukan proses eksekusi. Apabila dana dari investor dirasa kurang dalam pembukaan cabang baru, maka dana investasi tambahan dapat dihimpun dari pemilik lahan maupun masyarakat umum.

\section{Penggunaan Akad Musyarakah dengan Investor (Mitra Kerja)}

Syarat menjadi seorang investor di toko Basmalah pun tergolong cukup mudah yaitu harus orang Muslim, pembukaan investor toko basmalah dilakukan sebanyak 2 kali dalam satu tahun dan bukan hanya anggota
Koperasi Pondok Pesantren (Kopontren) saja yang dapat berkontribusi namun juga masyarakat luar yang belum menjadi anggota.Investor yang telah menjadi anggota dapat dikatakan sebagai anggota khusus atau anggota yang menginvestasikan dananya lebih banyak dalam akad musyarakah sedangkan investor yang bukan seorang anggota dikatakan sebagai anggota umum.Berinvestasi dengan akad musyarakah pada toko Basmalah memberikan beberapa keuntungan, salah satunya adalah pembagian keuntungan hasil investasi yang melebihi keuntungan dari perbankan.Investasi pada perbankan mendapatkan keuntungan atau deviden $\pm 7 \%$ setiap tahunnya sedangkan toko Basmalah mampu memberikan lebih. Proses pembagian deviden pada toko bamslah dilakukan setiap setahun sekali pada saat Rapat Anggota Tahunan (RAT), karena pihak Basmalah mengikuti periodesasi tahun masehi atau biasanya dilaksanakan pada saat bulan Desember.

\section{Modal dan Bagi Hasil dengan Mitra}

Dalam konsep berbisnis basmalah menerapkan konsep bisnis berjamaah dimana basmalah mengambil dana yang dikumpulkan dari investor "berjamaah" untuk dijadikan modal dalam pembukaan toko baru. Sedangkan investor tunggal yang akan membuka toko baru bisa menggunakan akad ini untuk nmenutup 
kekurangan biaya pembukaan toko basmalah.Dalam konsep "berjamaah" basmalah memanfaatkan dana umat untuk ikut serta dalam usaha ini. Selain itu konsep berjamaah ini mengubah pandangan investor akan kepemilikan modal dalam pembukaan suatu toko. Ketika salah satu toko basmalah mengalami penurunan pengunjung atau sepi pemilik investor berjamaah akan berbelanja di toko basmalah sehingga perputaran bisnis akan terus berjalan.

Akad musyarakah yang diterapkan oleh Basmalah dalam bagi hasil sebagai pemilik modal yang dikumpulkan dari dana umat akan di bagikan dalam presentase 65\% untuk keuntungan investor tunggal sedangkan $35 \%$ untuk dana umat yang akan membuka cabang toko baru.Selain itu kemudahan dalam berinvestasi berjamaah yang dihimpun dari dana umat untuk bermitra dalam bisnis basmalah membutuhkan modal minimal 700 ribu rupiah dengan deviden pertahunnya $18 \%$ maka yang didapat oleh investor berjamaah.Untuk pembagian hasil oleh investor tunggal presentase yang di dapat sebesar $65 \%$ untuk pemilik modal tunggal dan $35 \%$ untuk basmalah.

\section{Syarat dan Prosedur Pembukaan Cabang} Baru

Ada beberapa syarat dan prosedur yang membuat toko basmalah dalam memilih cabang untuk pembukaan toko baru. Lokasi strategis adalah salah satu faktor diantara sekian banyak pertimbangan, banyak tempat-tempat di berbagai lokasi yang ingin di buka oleh basmalah namun tidak sedikit pula lokasi itu tidak sesuai sasaran pasar yang ditujukan. Maka dari itu pihak basmalah akan melalukan pengecekan terlebih dahulu penentuan titik-titik lokasi pembangunan toko Basmalah tersebut apakah strategis dan potensial untuk di bangun toko.Selain memperhatikan langkah-langkah pembukaan toko baru juga harus memperhatikan wilayah pembukaan toko itu sendiri, karena hal itu menentukan kekuatan dan kebutuhan pasar dari toko Basmalah itu sendiri. Apabila wilayah itu masih tidak ada toko Basmalah dan memang masyarakat membutuhkan untuk di bukanya toko baru maka pihak Basmalah akan melihat dan mensurvey apakah layak untuk di buka toko baru.

\section{v. SIMPULAN}

Berdasarkan hasil penelitian yang dilakukan dapat ditarik kesimpulan yaitu, Basmalah Sidogiri merupakan lembaga koperasi berbasis syariah yang sukses mengembangkan bisnisnya melalui pembukaan cabang baru di berbagai daerah dengan menerapkan akad-akad kerjasama yaitu mudharabah, musyarakah, ijarah, dan nadzar lajaj. Akad musyarakah merupakan akad yang paling banyak digunakan akad ini memiliki banyak keutungan yaitu mudah dalam menghimpun modal dari anggota 
Taufiqulhakim, et al/Jurnal Ekonomi Syariah Teori dan Terapan Vol. 6 No. 10 Oktober 2019: 2143-2157; PENERAPAN SYIRKAH MELALUI AKAD MUSYARAKAH BASMALAH SIDOGIRI PASURUAN

maupun non-anggota, proses untuk menjadi anggota sangat ringan cukup dengan modal sebesar Rp 700.000 dan para shoibul maal dapat merasakan ketenangan dan kesejahteraan jiwa melalui pemotongan zakat.

Dasar dari penerapan bisnis berjamaah toko Basmalah dalam pembukaan cabang baru terdapat dalam surat Yunus ayat 59 dan toko Basmalah telah mampu menerapkannya dengan baik. Penerapan bisnis berbasis Islam dapat dilihat dari proses pembukaan cabang baru dengan langkah awal mengajukan proposal kepada pihak Basmalah, mencari dan survei lahan, menjalin kesepakatan bagi hasil antara kedua belah pihak, pembagian keuntungan melalui RAT, dan adanya pemotongan zakat atas keuntungan yang didapat oleh para shoibul maal. Adapun tingkat bagi hasil yang biasa diterapkan adalah $35 \%$ bagi amil dan 65\% bagi shoibul maal, dengan tingkat keuntungan atau deviden mencapai 10\%-18\% pertahun bagi investor umum dan $200 \%$ bagi investor khusus setiap tahunnya melalui pengawasan toko Basmalah.

\section{Daftar Pustaka}

Abdullah bin Muhammad Ath-thayyar, Ensiklopedi Figh Muamalah Dalam Pandangan 4 Madzhab, (Yogyakarta: Maktabah Al-hanif, 2014),h.262
Abdullah Saeed, Menyoal Bank Syariah,

(Jakarta : Paramadina, 2004), hlm. 101- 102

Anggadini, S. D. 2014. Analisis Implementasi Syirkah Pada Koperasi. Jurnal Riset Akuntansi.Vol. VI No.1

Arwani, A. 2010. Studi Kritis Akad Pembiayaan Musyârakah Pada Perbankan Syari'ah. Jurnal Hukum Islam (JHI) Vol 8, No 1, ISSN (P): 1829-7382

Belshaw, Cyril S. 1981.Tukar-Menukar Tradisional dan Pasar Modern. Jakarta : Gramedia

Budiman, F. 2013. Karakteristik Akad Pembiayaan AlQardh Sebagai AkadTabarru'. Yuridika: Vol 28 No 3 ,

Dimyauddin Djuwaini, Pengantar Fiah Muamalah, (Yogyakarta: Pustaka Pelajar,

2008), hlm. 207- 209

Syaiful, Mokh Bakhri. 2014. SNF Group (1) Kopontren Sidogiri. (Online) (Diakses pada 11 April 2019 https://bmtugtsidogiri.co.id/berita220-snf-group-(1):-kopontrensidogiri.html)

Fatwa DSN-MUI NO. 08/DSN-MUI/IV/2000 tentang pembiayaan musyarakah.

Faidah, C \& Alrianingrum, S. 2013. Perekembangan Pasar Turi baru Surabaya Tahun 1971-1978. AVATARA, e-Journal Pendidikan Sejarah Voll, No 2, 
Taufiqulhakim, et al/Jurnal Ekonomi Syariah Teori dan Terapan Vol. 6 No. 10 Oktober 2019: 2143-2157; PENERAPAN SYIRKAH MELALUI AKAD MUSYARAKAH BASMALAH SIDOGIRI PASURUAN

Falikhatun. Iswati, S., Saleh, M. 2017. Produk Pembiayaan Sosial PadaPerbankanSyariah Di Indonesia.Jurnal Ekonomi dan Perbankan SyariahVol. 5. No.1,ISSN (cet): 2355-1755

Fatwa DSN MUI No. 08 Tahun Tentang Pembiayaan Musyarakah , 2000.

Fitria, T. N. 2016. Kontribusi Ekonomi Islam Dalam Pembangunan Ekonomi Nasional. JURNAL ILMIAH EKONOMI ISLAM VOL. 02, NO. 03, ISSN : 24776157

Ghadas, A.Z.A \& Ali, R.A.E. 2011.The Development of Partnership Based Structure In Comparison To the Concept of MushÉrakah (Sharikah) with Special Reference to Malaysia. Journal Of Islam In Asia, Spl. Issue, No. 2

Ghufron A. Mas'adi, Figh Muamalah Kontekstual, (Jakarta : PT. Raja Grafindo Persada,2002)

Haryoso, L. 2017. Penerapan Prinsip Pembiayaan Syariah (Murabahah) Pada BMT Bina Usaha Di Kabupaten Semarang.Jurnal Law and Justice Vol. 2 No. 1

Hidayat, M. R. 2015. Analisis Fikih Klasik Terhadap Badan Hukum Sebagai Aqid. AL-IQTISHADIYAH Jurnal Ekonomi Syariah dan Hukum Ekonomi Syariah Vol.2 No. 2 ISSN: 2442-2282

Hulaimi, A., Sahri, Huzaimi, M.2016. Etika Bisnis Islam Pedagang Sapi dan Dampaknya Terhadap
Kesejahteraan Pedagang di Kecamatan Masbagik Kabupaten Lombok Timur.EKSYAR: Jurnal Ekonomi Syari'ah, Vol. 03, No. 02 pISSN: 2355-438X

Isfandiar, A.A. 2009. Akad Mualamalah di Pasar Modal Syariah. Jurnal Hukum Islam (JHI) Vol 7, No 1 ISSN (P): 1829-7382

Moleong, L. J. (2012). Metode Penelitian Kualitatif. Bandung: Remaja Rosda Karya.

Musnaini, 2010. Perilaku Nasabah Non Muslim dalam Bauran Pemasaran Terhadap Keputusan Memilih Produk Bank Syariah di Kota Jambi. Jurusan Manajemen Fakultas Ekonomi Universitas JambiVol. 2 No. 1 ISSN: 2085-0972

Nasrun Haroen, Fiqh Muamalah, Jakarta: Gaya Media Pratama, 2007,h.12

Nur Khoirin, Menyoal Kesyari'ahan Bank Syariah (Studi Kasus Kerjasama Masyarakat CV. Miskasari dengan Bank Syariah Mega Indonesia Semarang), (Semarang : IAIN Walisongo Semarang, 2010)hlm. 1719.

Nuhyatia, I. 2013. Penerapan dan Aplikasi Akad Wakalah Pada Produk Jasa Bank Syariah.Economic: Jurnal Ekonomi dan Hukum Islam, Vol. 3, No. 2ISSN: 2088-6365

Permata, R. I., Yaningwati, F., \& Zahroh. (2014). Nalisis Pengaruh Pembiayaan Mudharabah Dan Musyarakah Terhadap Tingkat 
Profitabilitas (Return On Equity)

(Studi pada Bank Umum Syariah Yang Terdaftar di Bank Indonesia Periode 2009-2012). Jurnal Administrasi Bisnis (JAB), Vol. 12, No. 1.

Pusparini, M. D. 2015. Konsep Kesejahteraan dalam Ekonomi Islam (Perspektif Maqasid AsySyari'ah). Islam Economics Journal Vol.1 No. 1 ISSN: 2460-1896

Otoritas Jasa Kevangan (OJK). 2014. Statistik Perbankan Indonesia. Departemen Perizinan dan Informasi Perbankan, Deputi Direktur Publikasi dan Administrasi (IDAP)

Pramana, D \& Indrarini, R. 2017. Pembiayaan BPR Syariah Dalam Peningkatan Kesejahteraan UMKM Berdasarkan Maqashid Sharia. Jurnal Ekonomi dan Bisnis Islam, Vol. 3, No. 1,

Rosni. 2017. Analisis Tingkat Kesejahteraan Masyarakat Nelayan di Desa Dahari Selebar Kecamatan Talawi Kabupaten Batubara. Jurnal Geografi Vol 9 No. 1 ISSN: 20858167

Sa'diyah, M \& Aziroh, N. 2014. Musyarakah Dalam Fiqih dan Perbankan Syariah. EQUILIBRIUM Vol. 2 No. 1

Santoso, H \& Anik. 2015. Analsiis Pembiayaan ljarah pada Perbankan Syariah.Jurnal IImiah Ekonomi Islam Vol. 01, No. 02,
Sardar, Z \& Nafik, M. H. R. 2016. Kesejahteraan dalam Perspektif Islam Pada Karyawan bank Syariah. Jurnal Ekonomi Syariah Teori dan Terapan Vol. 3 No

Sholikah. 2017. Pasar Turi Buka Pusat Perbelanjaan Syariah. http://www.republika.co.id/berita/ ekonomi/syariahekonomi/17/05/23/oqeirf368-pasarturi-buka-pusat-perbelanjaansyariah diakses pada 22 November 2017

Sitepu. N. I. 2016. Perilaku Bisnis Nabi Muhammad SAW Sebagai Entrepeneurship Dalam Filsafat Ekonomi Islam. HUMAN FALAH Vol. 3. No. 1

Sodiq, A. 2015. Konsep Kesejahteraan dalam Islam. EQUILIBRIUM Vol. 3 No. 2

Sugiyono. (2012). Metode Penelitian Kualitatif dan R\&D. Bandung: Alfabeta.

Suhendi, Hendi. 2017. Figh Muamalah. Jakarta: PT Raja Grafindo Persada.

Suryani. 2014. Industri Perbankan Syariah Dalam Cerminan Aspek Sharia Governance. Jurnal EconomicaVol. 5Edisi. 1

Suryono, A. 2014. Kebiajakan Publik Untuk Kesejahteraan

Rakyat.TRANSPARANSIJurnal IImiah IImU Administrasi Vol, 6 No, 2 ISSN 2085-1162

Suryanto, A. 2016. Penerapan Konsep Syirkah-Mudharabah dalam 
Taufiqulhakim, et al/Jurnal Ekonomi Syariah Teori dan Terapan Vol. 6 No. 10 Oktober 2019: 2143-2157; PENERAPAN SYIRKAH MELALUI AKAD MUSYARAKAH BASMALAH SIDOGIRI PASURUAN

Kegiatan Ekonomi Masyarakat di

Tasikmalaya. EKSYAR: Jurnal

Ekonomi Syari'ah, Vol. 03, No. 01

ISSN: 2407-3709

Wahbah az-Zuhaili, Fiqih Islam 5, (Depok :

Gema Insani, 2011), hlm. 441.

Wahyuni, M. Anuitas Di Perbankan Syariah.PRESTASI VOL. 13 NO. 1 ISSN $1411-1497$

Wibowo, A., \& Sunarto. (2016). Pengaruh Pembiayaan Mudharabah Dan Musyarakah Terhadap Profitabilitas Perbankan Syariah (Studi Kasus pada Bank Pembiayaan Rakyat Syariah Daerah Istimewa
Yogyakarta yang terdaftar di Bank Indonesia Periode 2012-2014). Syariah Paper Accounting FEB UMS. Widyastuti, A. 2012. Analisis Hubungan Antara Produktivitas Pekerja dan Tingkat Pendidikan Pekerja Terhadap Kesejahteraan Keluarga di jawa Tengah Tahun 2009.Economics Development Analysis Journal Vol. 1 No. 2 ISSN 2252-6560

Zainul Arifin, Dasar-dasar Manajemen Bank Syariah, (Jakarta : Pustaka Alvabet, 2006), hlm. 18 